Bulletin UASVM Food Science and Technology 70(1)/2013, 72-73

ISSN-L 2344-2344; Print ISSN 2344-2344; Electronic ISSN 2344-5300

\title{
Using Dehydrated Vegetables in Some Brown Bread Types
}

\author{
Simona MAN, Adriana PĂUCEAN* \\ Faculty of Food Science and Technology, University of Agricultural Sciences and Veterinary Medicine, 3- \\ 5 Mănăştur street, 3400, Cluj-Napoca, Romania \\ adriana.paucean@usamvcluj.ro
}

\begin{abstract}
Expanding the range of bakery products in terms of producing supplemented or dietetic products has been an increasingly important trend in contemporary baking. Bakery products as basic and popular food, could be used in the prevention of nutritive deficiencies of many important nutrients, by supplementing the products with biologically valuable ingredients. Such ingredients are dehydrated vegetables in the form of powder. For establishing the bread quality, a special importance shows it's chemical composition, because the substances that enter in it's constitution serve to obtaining the energy necessary to the human body. Beside the chemical composition, the bread quality and alimentary use, respectively, depends a large measure on a series of signs: flavor and taste, external appearance, crumb porosity and texture, breads' volume. This paper belongs to a more complex study, which aims are obtaining some bread assortments with high nutritional value, and improving their sensorial and rheological features, by adding dehydrated vegetables at different levels $4 \%$ potato flakes, $2 \%$ dehydrated onion, $0.5 \%$ dehydrated garlic and $2 \%$ dehydrated leek.
\end{abstract}

Keywords: dehydrated vegetables, brown bread quality, chemical composition

Introduction. Dehydrating vegetable is one of the oldest and easiest methods of food preservation. Dehydration is the process of removing water or moisture from a food product. Removing moisture from vegetables makes them smaller and lighter. Drying food is also a way of preserving seasonal vegetables for later use. By removing an important part of moisture (water) from vegetables, the microorganisms developing and the enzymatic reactions are slowed down. The drying of agricultural products can be undertaken in closed equipments (solar or industrial dryers) to guarantee the quality of the final product (Tatjana Rakcejeva et al., 2011).

Bread is one of the principal sources of energy, carbohydrate dietary fiber and a good source of protein for a large part of human population, provides high quantities of starch and dietary fibers, and little fat (Cvetković B. et al., 2009). It is a source of vitamins from the B group and minerals, mostly calcium, magnesium and iron. But many of these constituents are lost in industrial refining of cereal grains, so baking goods made from the white flour are in fact not very nutritious (Škrbić, Filipčev, 2007). There have been many attempts to increase the nutritive value of bakery products by addition of fruits and vegetables (H.P. Vasantha Rupasinghe et al., 2008; M.E. Camire et al., 2007; M.A. Larrea et al., 2005). In the baking industry there is requirement for high quality fruits and vegetable compounds with longer sustainability, which is achieved by using dried fruits and vegetables (Filipović N. et al, 2007).

Aims and objectives. This research work aimed to obtain several types of brown bread with dehydrated vegetables (potato flakes, dehydrated onion, dehydrated garlic and dehydrated leek) by adding them to the dough at different levels $(4 \%, 2 \%, 0.5 \%$ and $2 \%$,). The technological implications of these additions were studied by assessing the influences on the quality of the final products.

Materials and methods. The recipe used for obtaining bread with dehydrated vegetables, was the following one: brown flour $1000 \mathrm{~g}$, water $-64 \%$, yeast $-2.5 \%$, salt $-1,5 \%$, and dehydrated vegetables addition in various amounts: $4 \%$ potato flakes, $2 \%$, dehydrated onion, $0.5 \%$ dehydrated garlic and $2 \%$ 
dehydrated leek. Similarly, a control sample without dehydrated vegetables addition was performed. All raw materials used in these experiments have been purchased from markets of specialized stores.

After kneading the dough is maintained for 60 minutes at a temperature of 28 to $30^{\circ} \mathrm{C}$ for bulkfermentation, after which it is divided into two parts, with equal weight and is shaped in an oval shape. It is being put on trays and introduced in the fermentation room for 25 minutes at $35^{\circ} \mathrm{C}$ and relative humidity of $75 \%$. After fermentation, the products are baked at $230^{\circ} \mathrm{C}$ for 30 minutes using a ZANOLLI type oven equipped with a proofer.

The final breads were submitted to the physico-chemical and sensorial exams. The quality characteristics (volume, crumb porosity and elasticity, height/diameter ratio, moisture and acidity) were determined according to STAS 91-2007.

\section{Results and Discussion}

In combination with the flour, dehydrated vegetables (potato flakes, dehydrated onion, dehydrated garlic and dehydrated leek) improve the quality of the final breads. The values of analyzed parameters for studied samples are presented in Tab. 1.

Tab. 1

Values of analyzed parameters for studied samples

\begin{tabular}{|l|c|c|c|c|c|c|}
\hline \multirow{2}{*}{$\begin{array}{l}\text { Brown bread with the } \\
\text { dehydrated vegetable }\end{array}$} & \multicolumn{6}{|c|}{ Quality parameters } \\
\cline { 2 - 7 } & $\begin{array}{c}\text { Volume, } \\
\mathrm{cm}^{3}\end{array}$ & $\begin{array}{c}\text { Porosity, } \\
\%\end{array}$ & $\begin{array}{c}\text { Elasticity, } \\
\%\end{array}$ & $\begin{array}{c}\text { Humidity, } \\
\%\end{array}$ & $\begin{array}{c}\text { Acidity, } \\
\%\end{array}$ & $\begin{array}{c}\text { Height/Diameter } \\
\text { ratio }\end{array}$ \\
\hline Control sample & 340 & 63.09 & 92.83 & 45.06 & 4.07 & 0.498 \\
\hline 4\% potato flakes & 342 & 60.25 & 89.34 & 47.13 & 4.18 & 0.505 \\
\hline $2 \%$ dehydrated onion & 358 & 61.14 & 90.79 & 43.44 & 3.68 & 0.515 \\
\hline $0.5 \%$ dehydrated garlic & 363 & 62.06 & 91.17 & 43.21 & 3.16 & 0,534 \\
\hline $2 \%$ dehydrated leek & 367 & 62.47 & 91.75 & 45.06 & 3.34 & 0,538 \\
\hline
\end{tabular}

By comparing with the control bread, higher volume, better texture and taste were identified. It can be said that, regardless of the type of the dehydrated vegetable added in the dough, the final bread is proportional, specific to the assortment and with improved sensorial properties.

\section{Conclusion}

Analyzing the four experimental variants (the addition of $4 \%$ potato flakes, $2 \%$, dehydrated onion, $0.5 \%$ dehydrated garlic and $2 \%$ dehydrated leek.), both in terms of physico-chemical and sensorial,quality parameters were framed the limits specified by STAS.

In this research work, we demonstrated that this innovative bread formulations obtained by adding dehydrated vegetables at levels between $0.5-4 \%$ are successful.

\section{REFERENCES}

1. Tatjana Rakcejeva, Ruta Galoburda, Liga Cude, Envija Strautniece, 2011, Use of dried pumpkins in wheat bread production, Procedia Food Science 1, 441 - 447

2. Rajarathnam Ezekiel, Narpinder Singh., 2011, Use of Potato Flour in Bread and Flat Bread, Flour and Breads and their Fortification in Health and Disease Prevention, 247-259

3. Biljana R. Cvetković, Bojana V. Filipčev, Marija I. Bodroža-Solarov, Željko M. Bardić, Marijana B. Sakač, 2009, Chemical composition of dried fruits as a value added ingredient in bakery products, Food Processing, Quality and Safety 1-2, 15-19. 